\title{
On the Determination of Mechanical Properties of Aqueous Microgels-Towards High-Throughput Characterization
}

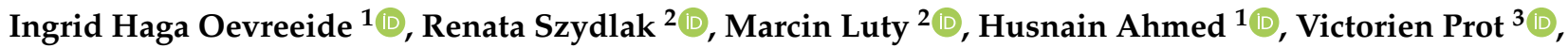 \\ Bjørn Helge Skallerud ${ }^{3}$, Joanna Zemła ${ }^{2} \mathbb{D}$, Małgorzata Lekka ${ }^{2, *}$ and Bjørn Torger Stokke ${ }^{1, *} \mathbb{C}$ \\ 1 Biophysics and Medical Technology, Department of Physics, NTNU The Norwegian University of Science \\ and Technology, NO-7491 Trondheim, Norway; ingrid.h.ovreeide@ntnu.no (I.H.O.); \\ husnain.ahmed@ntnu.no (H.A.) \\ 2 Institute of Nuclear Physics, Polish Academy of Sciences, PL-31342 Krakow, Poland; \\ renata.szydlak@ifj.edu.pl (R.S.); marcin.luty@ifj.edu.pl (M.L.); joanna.zemla@ifj.edu.pl (J.Z.) \\ 3 Biomechanics, Department of Structural Engineering, NTNU The Norwegian University of Science and \\ Technology, NO-7491 Trondheim, Norway; victorien.prot@ntnu.no (V.P.); bjorn.skallerud@ntnu.no (B.H.S.) \\ * Correspondence: malgorzata.lekka@ifj.edu.pl (M.L.); bjorn.stokke@ntnu.no (B.T.S.)
}

check for updates

Citation: Oevreeide, I.H.; Szydlak, R.; Luty, M.; Ahmed, H.; Prot, V.; Skallerud, B.H.; Zemła, J.; Lekka, M.; Stokke, B.T. On the Determination of Mechanical Properties of Aqueous Microgels-Towards HighThroughput Characterization. Gels 2021, 7, 64. https://doi.org/10.3390/ gels7020064

Academic Editor: Ferenc Horkay

Received: 23 April 2021

Accepted: 25 May 2021

Published: 31 May 2021

Publisher's Note: MDPI stays neutral with regard to jurisdictional claims in published maps and institutional affiliations.

Copyright: (C) 2021 by the authors. Licensee MDPI, Basel, Switzerland. This article is an open access article distributed under the terms and conditions of the Creative Commons Attribution (CC BY) license (https:// creativecommons.org/licenses/by/ $4.0 /)$

\begin{abstract}
Aqueous microgels are distinct entities of soft matter with mechanical signatures that can be different from their macroscopic counterparts due to confinement effects in the preparation, inherently made to consist of more than one domain (Janus particles) or further processing by coating and change in the extent of crosslinking of the core. Motivated by the importance of the mechanical properties of such microgels from a fundamental point, but also related to numerous applications, we provide a perspective on the experimental strategies currently available and emerging tools being explored. Albeit all techniques in principle exploit enforcing stress and observing strain, the realization differs from directly, as, e.g., by atomic force microscope, to less evident in a fluid field combined with imaging by a high-speed camera in high-throughput strategies. Moreover, the accompanying analysis strategies also reflect such differences, and the level of detail that would be preferred for a comprehensive understanding of the microgel mechanical properties are not always implemented. Overall, the perspective is that current technologies have the capacity to provide detailed, nanoscopic mechanical characterization of microgels over an extended size range, to the high-throughput approaches providing distributions over the mechanical signatures, a feature not readily accessible by atomic force microscopy and micropipette aspiration.
\end{abstract}

Keywords: microgel; AFM; micropipette aspiration; high-throughput; mechanics

\section{Introduction}

Mechanical properties of polyelectrolyte hydrogels are a fundamental characteristic that has been extensively addressed both experimentally and theoretically. Most of the approaches investigate bulk specimens of these soft materials. In the present perspective, we summarize efforts directed towards the determination of mechanical properties of small specimens in the form of microgels. The rationale for the focus on microgels is related to the large interest in exploiting polyelectrolyte hydrogel materials in the form of microgels both to address fundamental issues and in numerous applications. Furthermore, the microgel mechanical properties may differ from that of the bulk specimens of the same constituents either due to statistical variation of mechanical properties of microgels due to structural heterogeneity [1], combination of materials to yield multicomponent microgels different from that possible in bulk [2], coating of the microgels with the possible consequence of the mechanically stratified structure and immobilization of components in the microgels [3-5].

Microgels are already present in various domains serving as materials for developing lubricants [6], 3D bioprinting [7], 3D cell culture supports [8], sensors [9] and plugging of porous media [10]. Microgel properties such as size and size distribution, colloidal stability, 
swelling, environmental responsivity, and mechanical properties are important for such applications. These properties can be designed and tailored by their synthesis conditions, including choice and concentration of monomer, co-monomer(s) and crosslinking agents. The various concentrations of the components and the distribution of crosslinking sites are the most important parameters influencing the mechanical properties of the microgels. Thus, the understanding of how mechanical properties vary in response to the type of the solvent, its composition, the presence of divalent ions and the concentration of crosslinking agents is of great importance.

In the following, we summarize conventional strategies for determining the mechanical properties of aqueous microgels. This includes techniques such as micropipette aspiration [11,12], optical tweezer and stretcher [13], atomic force microscopy [14-16], and, more recently, microfluidic-based approaches to provide distribution of the mechanical properties [17-19], and also Brillouin scattering based imaging [20]. Schematic presentations of some of these strategies are shown in Figure 1. Microgel mechanical properties can also be deduced from methods such as inferred from calorimetry [21], magnetic microdisc rheometer [22] or bulk rheological measurement of close-packed microgel dispersions [23]. Most of the approaches share the principle of analyzing deformation-stress relations for the actual physical realization of the experiments, which may also include explicit material models and distribution of the mechanical properties. We thus summarize relevant aspects as underpinning the various techniques, targeting both a basis for the analysis as well as a comparison between the different experimental approaches. An important part of this is possible differences in the rate of deformation/stress, or frequency for the corresponding cyclic experiment for the obtained mechanical properties. Thus, awareness of the dynamics of the obtained mechanical properties is an essential facet in the understanding of the aqueous, including polyelectrolyte microgels as well as in the comparison of the experimental approaches.

a)

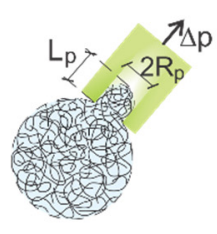

b)

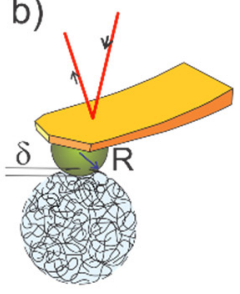

c)

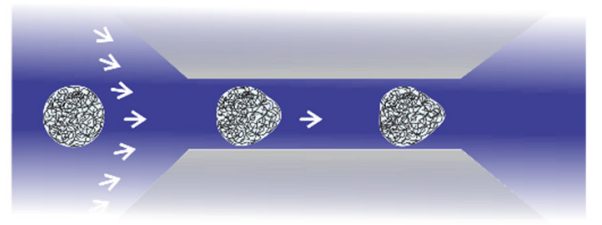

Figure 1. Schematic illustrations of micropipette aspiration (a), atomic force microscopy-based nanoindentation (b) and squeezing in microchannel confinement (c) for characterization of mechanical properties of microgels. In micropipette aspiration (a), a suction pressure $(\Delta \mathrm{p})$ applied by a micropipette with inner radius $R_{p}$, in contact with the microgel leads to suction with length $L_{p}$ of part of the microgel in the pipette. Analysis of experimentally determined $\mathrm{L}_{\mathrm{p}}$ as a function of $\Delta \mathrm{p}$ combined with appropriate material model yields an estimate of mechanical properties; (b) Schematic illustration of colloidal bead (radius R) tip geometry on an AFM cantilever indenting a microgel with total indentation $\delta$; (c) Illustration of microgels in a fluid stream in a constriction channel with cross-sectional dimensions larger than the microgel being deformed due to the distribution of stress imposed on the microgels by the flow field.

The paper is organized in the following by first giving examples of relevant experimental preparation approaches exploited for the fabrication of microgels; then methods not supporting high-throughput characterization such as atomic force microscopy and micropipette aspiration are presented. This is followed by summarizing high-throughput strategies as, e.g., supported by flow techniques in microfluidic channels before also alluding to some emerging approaches for the field. Relevant examples are included alongside the discussions of the individual techniques, and the perspective is concluded by comparing the various approaches. 


\section{Fabrication of Microgels}

A brief account of strategies employed for the preparation of microgels is included since this is required for any subsequent mechanical characterization unless the sample occurs naturally. Generally, the preparation of micro- and nanogels is realized using a range of materials and strategies as recently reviewed [24,25]. Microgel synthesis can be stated to require a monomer, crosslinker and initiator, for either of the two main preparation routes being based on emulsions in bulk or as supported by microfluidic approaches. Several different techniques can be employed for the formation of such microgel spheres. These microgels are typically spherical and with a diameter scaling from $100 \mathrm{~nm}$ to several hundred micrometers.

There are several different strategies that can be employed for bulk preparation of microgels, such as precipitation polymerization, spray drying, membrane emulsification and using template molds (Table 1). The chosen strategy will depend on the microgel properties and applications, as these will determine the appropriate use of solvents, UVlight, temperature and $\mathrm{pH}$-initiated polymerization processes. Controlling the ratios of the components as well as temperature and $\mathrm{pH}$ may offer strategies to affect the size, shape, polydispersity, elasticity and overall microgel yield [26].

Microgel elasticity is tuneable through the selection of composition, and crosslinker concentration, and can also be affected by temperature and hydration levels. The addition of low concentrations of crosslinker resulted in the formation of ultralow crosslinked microgels, which can be further used as biomimetic particles. Muller et al. utilized ultrasound to enhance microgel deformation, as controlled deformation can be desired in several biomedical applications, such as drug delivery. The deformation of such microgels has also been observed to influence their biocompatibility [27]. Increasing the crosslinker (PEGDMA) concentration from $1 \%$ to $11 \%$ resulted in a change in shear modulus $\left(G^{\prime}\right)$ of the microgel from $1.1 \pm 0.1 \mathrm{kPa}$ to $17 \pm 1 \mathrm{kPa}$ [28]. A similar effect was also observed when crosslinker PEGDA was added at 1 and $10 \%$, resulting in the modulus increasing from $7.8 \pm 1 \mathrm{kPa}$ to $63.9 \pm 15.7 \mathrm{kPa}$ [29]. Thus, the change in mechanical properties of these microgels also depends on the type of crosslinker implemented.

The elasticity of single microgel particles was determined when the particle underwent a deswelling process due to temperature changes [30]. In this instance, an increase in temperature from $300 \mathrm{~K}$ to $313 \mathrm{~K}$ resulted in both a decrease in the size and a corresponding increase in Young's modulus from $8 \pm 1.4 \mathrm{kPa}$ to $86 \pm 22 \mathrm{kPa}$. Such microgels have also been used in regenerative medicine. In one instance, a doubly crosslinked microgel was injected into degenerated intervertebral discs to improve the mechanical properties. Subsequent cell mobility studies in matrices prepared by embedding the microgels in a fibril polymer network were shown to vary the cell migration rates depending on the elasticity of the microgels [31].

As illustrated by the examples above, the mechanical properties of microgels are essential in biological applications, from the proliferation and viability of cells to microgels' migration in physiologically relevant environments. A key facet here is the cells' ability to sense the elastic/mechanical properties of their environment and they can respond to this in a chemical manner which can then change the cell properties and thus also their behavior [32]. Therefore, it is important to measure and know the mechanical properties of the different microgels that can be produced, especially within this field. 
Table 1. Examples of bulk fabrication strategies to prepare microgels *

\begin{tabular}{c}
\hline Monomer and Crosslinker \\
EGDMA-PolyEGDMA \\
Co-polymerization of \\
Divinylbenzene-PolyEGDMA-co-DVB \\
Co-polymerization \\
MAA-PEGMM, EDMA crosslinker
\end{tabular}

PEG-DA, crosslinked using Tetra-thiol + UV light

Co-polymerization

$\mathrm{N}$-isopropylacrylamide (NIPPAm) and acrylic acid

(Acc), crosslinked using BIS (0.1,1 and $10 \mathrm{wt} \%)$

$$
\text { Co-polymerization }
$$

PVA -PEGMMA, crosslinked using PEGDMA (1-11\%) and HEMA4L46 (3\%)

Surfactant-free emulsion polymerization

\section{Precipitation polymerization}

Ref.

PolyEGDMA: 1.18-2.27 $\mu \mathrm{m}$ (PDI = 1.006-1.035).

PolyEGDMA-co-DVB: 1.93-2-45 $\mu \mathrm{m}$ (PDI = 1.006-1.019).

Size:

$0.45-3.25 \mu \mathrm{m}$ depending on reactant conc.

$0.77 \mu \mathrm{m}(0.44 \%)-2.79 \mu \mathrm{m}(20.3 \%)$ depending on solvent. Size:

$$
1.76 \pm 0.26 \mu \mathrm{m} . \text { PDI }=1.26(n<200) \text {. }
$$

Size:

$$
2 \pm 0.5 \mu \mathrm{m} \text {. }
$$

Size after sieving between 315 and $500 \mu \mathrm{m}$ :

PEGDMA: $376 \pm 1 \mu \mathrm{m}$ to $462 \pm 2 \mu \mathrm{m}$.

HEMA4L46: $379 \pm 2 \mu \mathrm{m}$.

Elastic modulus $\left(\mathrm{G}^{\prime}\right)$ :

PEGDMA: $17 \pm 1 \mathrm{kPa}$ to $1.1 \pm 0.1 \mathrm{kPa}$.

HEMA4L46: $4.8 \pm 0.2 \mathrm{kPa}$.

Size:

$\mathrm{N}$-isopropylacrylamide, crosslinked using

$N, N^{\prime}$-methylenebisacrylamide

$700 \mathrm{~nm}$ (room temp), $300 \mathrm{~nm}(310 \mathrm{~K}), \mathrm{PDI}=7 \%$.

Young's modulus (E):

$8 \pm 1-4 \mathrm{kPa}(300 \mathrm{~K}), 86 \pm 22 \mathrm{kPa}(313 \mathrm{~K})$.

Size:

Co-polymerization

$\mathrm{N}$-isopropylacrylamide (NIPPAm) and acrylic acid (Acc) crosslinked using BIS (0, 2, 4 and 7\%)

Co-polymerization

MMA, MAA, EGD and GM

Microgels:

M-EGD, GM-E-EGD and DX microgels

AcGGM

Microgel: Hemicellulose

Chitosan core and Eudragit coat

\section{Membrane emulsification}

$760.3 \pm 14.7 \mathrm{~nm}$ to $821.8 \pm 47.0 \mathrm{~nm}$ depending on BIS concentration.

Seed-feed

Size:

GM-M-EGD:102 nm (C.V 16) and M-EGD:107 nm (C.V 18).

Storage modulus $\left(\mathrm{G}^{\prime}\right)$ :

DX microgel storage modulus: 72.9-134 kPa. Spray drying

$2.0 \pm 1.0 \mu \mathrm{m}$ (pure), $1.3 \pm 0.3 \mu \mathrm{m}, 2.7 \pm 2.2 \mu \mathrm{m}$ depending on added functional material.

Core size: $1.8 \pm 1.1 \mu \mathrm{m}$ to $2.9 \pm 1.7 \mu \mathrm{m}$ depending on solvent and chitosan type.

Core-coat size: $152 \pm 4 \mu \mathrm{m}$ to $223 \pm 6 \mu \mathrm{m}$. Depending on Eudragit type and core/coat ratio.

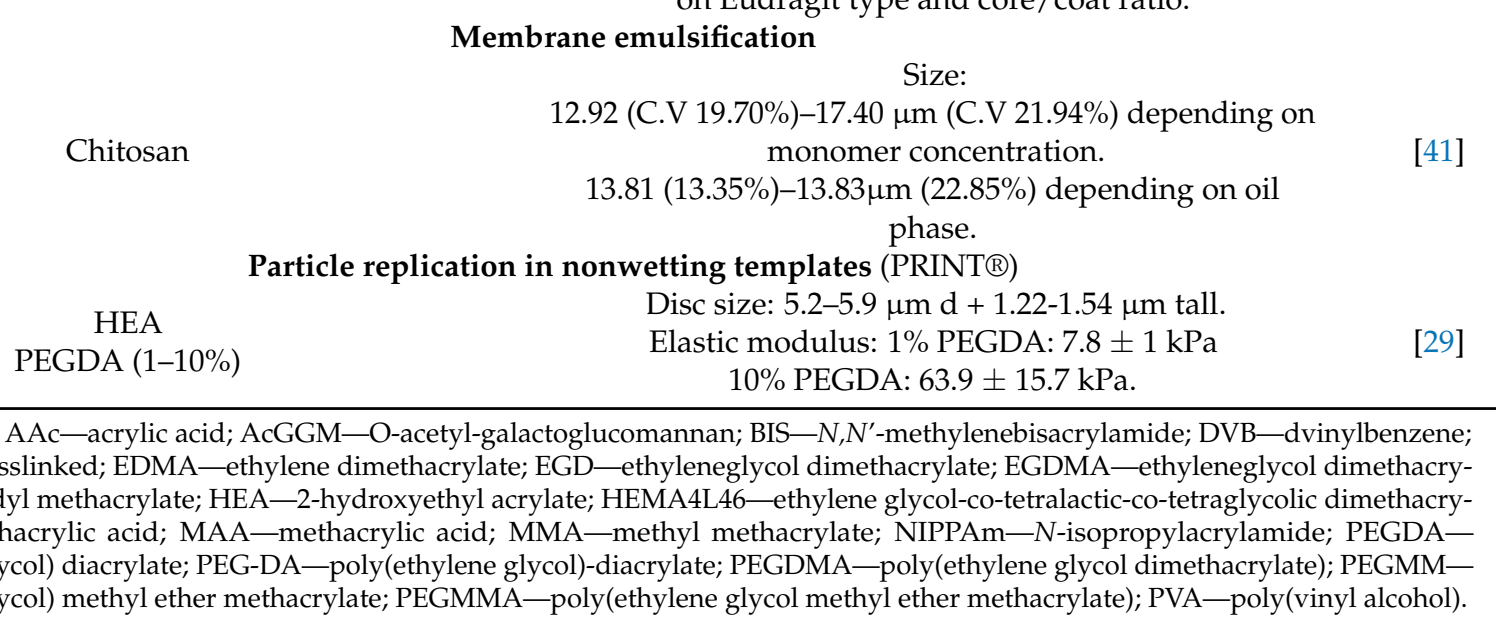

Microfluidic-assisted hydrogel beads' fabrication is another synthesis route, possibly offering more explicit control of the resulting size of near monodisperse samples than

\begin{abstract}
* Abbreviations: AAc—acrylic acid; AcGGM-O-acetyl-galactoglucomannan; BIS—N,N'-methylenebisacrylamide; DVB—dvinylbenzene; DX—doubly crosslinked; EDMA—ethylene dimethacrylate; EGD—ethyleneglycol dimethacrylate; EGDMA—ethyleneglycol dimethacrylate; GM-glycidyl methacrylate; HEA-2-hydroxyethyl acrylate; HEMA4L46 - ethylene glycol-co-tetralactic-co-tetraglycolic dimethacrylat; MAA-methacrylic acid; MAA - methacrylic acid; MMA - methyl methacrylate; NIPPAm- $N$-isopropylacrylamide; PEGDApoly(ethylene glycol) diacrylate; PEG-DA — poly(ethylene glycol)-diacrylate; PEGDMA—poly(ethylene glycol dimethacrylate); PEGMMpoly(ethylene glycol) methyl ether methacrylate; PEGMMA - poly(ethylene glycol methyl ether methacrylate); PVA—poly(vinyl alcohol).
\end{abstract}


the above summarized methods. The microfluidic approach is widely exploited due to its ability to provide three-dimensional support to biological entities since it also allows their inclusion in the process [42,43]. Fabrication of microgels using this route hasbeen reported for various polymers using either physical or chemical gelation strategies (Table 2 and $[44,45])$. The chemical gelation methods mostly induce the gelation of synthetic polymers such as PEG and acrylamides by photoinitiated or redox-initiated polymerization, which are synthesis strategies also employed in bulk approaches. When selecting polymers and crosslinking method for the microfluidic-assisted fabrication of microgels, consideration of facets such as, e.g., crosslinking method, compatibility of the polymer with end-use of the microgels, ease of emulsification and compatibility with encapsulation capacities, represent a basis for the actual selection. With respect to crosslinking, the example of the production of Janus microgels by applying UV radiation on an aqueous emulsion of monomers to initiate the chemical reaction $[18,46,47]$ illustrate the need to consider adverse effects of the crosslinking process. This method produces mechanically strong microgels, but UV radiation could be harmful to biological molecules.

Ionic gelation can generate microgel beads by on-chip emulsification at the pregel state followed by coalescence of aqueous droplets including the crosslinker, e.g., aqueous sodium alginate and crosslinking agent $\left(\mathrm{CaCl}_{2}\right)$. Diffusion of a crosslinking agent such as $\mathrm{Ca}^{2+}$ or $\mathrm{Fe}^{3+}$ ions from continuous phase to emulsified precursor has also been suggested [48]. Among the various approaches reported (Table 2), some of the them require a change of $\mathrm{pH}$ in the post-emulsification region, whereas others proceed at constant $\mathrm{pH}$. The challenge associated with the reduced $\mathrm{pH}$ in the examples with alginate microgels has been addressed in the method of competitive ligand exchange reaction [49]. This approach exploits a gelling ion-chelator and exchange ion-chelator combination that satisfy the order of association constants for a cascading exchange when the two streams meet just before the emulsification in a flow-focusing device. While stable and non-reactive before being blended, the merger of the two aqueous streams induces the release of the gel-inducing ions by a displacement from the exchange ion. This cascading process proceeds at constant $\mathrm{pH}$ compatible with living cell requirements.

Table 2. Examples of microfluidic-assisted microgel fabrication processes *

\begin{tabular}{|c|c|c|c|c|c|}
\hline Polymer & Microfluidic Device & Sample Properties & Crosslinking & $\begin{array}{l}\text { Properties of } \\
\text { Microgels; }\end{array}$ & Ref \\
\hline \multirow[t]{4}{*}{ Alginate } & $\begin{array}{l}\text { Flow focusing for } \\
\text { alginate } \\
\text { emulsification, } \\
\text { T-junction of } \mathrm{Ca} \\
\text { emulsification }\end{array}$ & $\begin{array}{c}\eta=48 \mathrm{mPas} \text { at } \\
\mathrm{c}_{\mathrm{p}}=1.5 \%\end{array}$ & $\begin{array}{l}\text { Ca induced. Coalescence between } \\
\text { emulsified alginate and Ca droplets. } \\
\text { Constant } \mathrm{pH} .\end{array}$ & $\begin{array}{l}\text { Non-spherical } \\
\text { microgels with size in } \\
\text { the range } 150-100 \mu \mathrm{m} \\
\varnothing \text { depending on flow } \\
\text { rates. } C V \text { of size: } \\
6.4 \% \text {. }\end{array}$ & {$[42,43]$} \\
\hline & Flow focusing & $\begin{array}{c}\text { Pronova UP MVG, } \\
\text { Novamatrix } \\
c_{\mathrm{p}}=2.0 \%\end{array}$ & $\begin{array}{l}\text { Ca induced. Emulsified alginate } \\
\text { with Ca-EDTA, Ca released from } \\
\text { EDTA by acetic acid diffusing from } \\
\text { oil phase after emulsification. }\end{array}$ & $\begin{array}{l}\text { Disc-like hydrogels. } \\
\text { Spherical microgels } \\
\text { with size in the range } \\
17-50 \mu \mathrm{m} \varnothing \\
\text { depending on flow } \\
\text { rates. pH } 5 \text { in } \\
\text { microgels. }\end{array}$ & [50] \\
\hline & Flow focusing & Alginate, $c_{p}=2 \%$ & $\begin{array}{l}\text { Ca induced. Emulsfied alginate } \\
\text { with } \mathrm{CaCO}_{3} \text {; increasing } \mathrm{Ca} \\
\text { solubility from the carbonate by } \\
\text { acetic acid diffusing from the } \\
\text { continuous phase. pH reduced }\end{array}$ & $\begin{array}{l}\text { Nearly spherical } \\
\text { microgels with size in } \\
\text { the range } 54-72 \mu \mathrm{m} \\
\varnothing \text { obtained by } \\
\text { varying flow rates. }\end{array}$ & {$[51,52]$} \\
\hline & $\begin{array}{l}\text { Flow focusing of dual } \\
\text { inlet aqueous } \\
\text { solutions }\end{array}$ & $\begin{array}{c}\mathrm{M}_{\mathrm{w}}=268 \mathrm{kDa} \\
\mathrm{F}_{\mathrm{G}}=0.68 ; \text { used at } \\
\mathrm{c}_{\mathrm{p}}=0.8 \%\end{array}$ & $\begin{array}{l}\text { Ca induced by competitive ligand } \\
\text { exchange from different chelators at } \\
\text { constant pH (user controlled in the } \\
\text { range from } 8 \text { to } 5 \text { ). }\end{array}$ & $\begin{array}{l}\text { Spherical micgrogels } \\
\text { with size } 50 \mu \mathrm{m} \varnothing\end{array}$ & [49] \\
\hline K-carra-geenan & Flow focusing & $\begin{array}{c}\mathrm{M}_{\mathrm{w}}=1000 \mathrm{kDa}, \\
\text { Copenhagen } \\
\text { Hercules } \\
\mathrm{c}_{\mathrm{p}}=0.8 \%\end{array}$ & $\begin{array}{l}\text { Ca induced by including } \mathrm{CaCl}_{2} \text { in } \\
\text { the continuous phase }\left(0.25 \% \mathrm{CaCl}_{2}\right. \\
\text { in undecanol). }\end{array}$ & $\begin{array}{l}\text { Spherical microgels } \\
\text { with size about } \\
65 \mu \mathrm{m} \varnothing \text { obtained at } \\
\text { given flow rates. }\end{array}$ & [53] \\
\hline
\end{tabular}


Table 2. Cont.

\begin{tabular}{|c|c|c|c|c|c|}
\hline Polymer & Microfluidic Device & Sample Properties & Crosslinking & $\begin{array}{l}\text { Properties of } \\
\text { Microgels; }\end{array}$ & Ref \\
\hline Pectin & Flow focusing & $\begin{array}{c}\mathrm{M}=(239.5 \pm 10.5) \\
\mathrm{kDa} ; 24 \% \text { amidation, } \\
23 \% \text { esterification; } \\
\mathrm{c}_{\mathrm{p}}=1-10 \%\end{array}$ & $\begin{array}{c}\text { Ca induced; } 4 \mathrm{M} \mathrm{CaCl}_{2} \text { dispersed at } \\
\text { ratio } 1: 3 \text { in mineral oil with } 2 \mathrm{wt} \% \\
\text { span } 80 .\end{array}$ & $\begin{array}{l}\text { Spherical microgels } \\
\text { with } \varnothing \sim 70 \mu \mathrm{m} \text { and } \\
\mathrm{CV} \text { of } 3.5 \% \text { obtained } \\
\text { under some } \\
\text { conditions. }\end{array}$ & [48] \\
\hline Gelatin & & $\begin{array}{l}\text { Calf bone gelatin, } 300 \\
\text { Bloom; } \mathrm{c}_{\mathrm{p}} \text { of } 5 \% \text { in } \\
\text { water at pH } 7.4\end{array}$ & $\begin{array}{l}\text { Thermosetting: Emulsified by } \\
\text { extrusion through microchannel } \\
\text { plate, at } 40^{\circ} \mathrm{C} \text { and collected in } \\
\text { continuous phase as } 25^{\circ} \mathrm{C} \text {, } \\
\text { subsequently cooled to } 5^{\circ} \mathrm{C} \text {. }\end{array}$ & $\begin{array}{l}\text { Spherical microgels } \\
\text { with diameter } \\
31.6 \mu \mathrm{m} \text {, relative S.D. } \\
\text { of } 7.3 \% \text {. }\end{array}$ & [54] \\
\hline $\begin{array}{c}\text { Hyaluronic acid } \\
\text { derivatives }\end{array}$ & $\begin{array}{l}\text { Flow focusing for } \\
\text { initial emulsification } \\
\text { of aqueous pregel, } \\
\text { crosslinking initiator } \\
\text { added in } \\
\text { downstream junction }\end{array}$ & $\begin{array}{l}\text { Hyaluronic acid } \\
\text { derivatives. HA base } \\
\text { polymer Mw 40-65 } \\
\text { kDa }\end{array}$ & $\begin{array}{c}\text { Passerini type X-linking using PEG } \\
\text { dialdehyde initiated by compound } \\
\text { added in the second junction; } \\
\text { diffusing initiator from continous } \\
\text { phase. }\end{array}$ & $\begin{array}{l}\text { Spherical microgels } \\
\text { wih tunable size, the } \\
\text { range } 70-90 \mu \mathrm{m} \\
\text { diameter shown } \\
\text { explicitly. }\end{array}$ & {$[20]$} \\
\hline
\end{tabular}

* Symbols used: $\eta$-viscosity; $c_{p}$ - polymer concentration; $M$-molar mass; $\mathrm{M}_{\mathrm{w}}$-weight-average molar mass; $\mathrm{F}_{\mathrm{G}}$-fraction of $\alpha$-L-GulA in alginate (the other sugar residue is $\beta$-D-ManA); CV relative to variation in size.

While the microfluidic-assisted approaches provide excellent control of mean population size and mono-dispersity of synthesized microgel samples, e.g., as illustrated by the polymer particle size distributions reported for microfluidics route as compared to the bulk emulsification [55], there are current limitations in throughput [4] that should be relaxed to provide a larger amount of samples. Thus, devices supporting massive multiplexing for droplet generation demonstrated for aqueous phase with viscosity up to $155 \mathrm{mPas}$ represent an interesting innovation that could pave the way for enhanced hydrogel bead fabrication rates [56]. Another approach is the in-air-microfluidic approach demonstrating a 10-100 fold improved fabrication rate of microgel-like particles compared to the microfluidic device-based microgel synthesis and also maintaining capabilities such as fabrication of Janus microgel particles [57,58]. Overall, there is a wide range of described methods that can be exploited to synthesize a particular microgel, offering versatility in polymer compositions and their distributions, that also allow for immobilization of living organisms [59]. This is an important toolbox underpinning sample design and realization of polyelectrolyte microgel samples for mechanical characterization.

For the majority of bulk fabrication processes, there are extensive purification and washing steps involved, as there are often uncreated reagents present in the bulk emulsion after reaction completion; thus, increasing the time and complexity of the overall microgel process compared to microfluidic processes. This is exemplified by the need for micro sieves with mesh sizes ranging from 40-630 $\mu \mathrm{m}$ showing overall low control of particle dispersity [28], or the need for removing unreacted reagents over a 5-day period [36]. Thus, biocompatibility, degradability and stability to external variations are also factors that must be considered when selecting an appropriate fabrication procedure.

\section{Application of AFM to Determine Mechanical Properties of Microgels}

Atomic force microscopy (AFM) is a widely used technique employed to quantify the mechanical properties of various soft materials, including hydrogels [60], microgels [61] and living cells [62]. In the AFM, the sample is attached to a support placed, typically, on a piezoelectric $X Y$ scanner. A cantilever with a probing tip mounted at the free end of the cantilever deflects due to forces acting between the tip and the sample surface. To detect the deflection, typically, an optical system is used, in which a laser beam is focused on the cantilever free end, just above the probing tip. The reflected laser beam is registered by a position-sensitive photodetector (a photodiode). The active area of the detector is, typically, divided into four quadrants, two top and two bottom ones. The forces acting perpendicularly to the investigated surface move the cantilever up and down what translates to the difference between top and bottom quadrants, expressed in volts. 
The difference is converted into force by multiplying it by the cantilever spring constant $(\mathrm{N} / \mathrm{m})$ and photodetector sensitivity relating volts with nanometers. The advantage of the AFM is the capability to carry out the measurements in liquid conditions making this technique particularly suitable for measuring microgels in the actual solvent conditions. As required by the AFM method, the microgels had to be first adsorbed/adhered at a solid surface to render mechanical testing reliable [14]. AFM working in force spectroscopy mode delivers the force curves (relations between the force and the relative scanner/sample position) measured on the stiff, non-deformable surface and soft material. By subtracting these curves from each other, a force versus indentation depth curve is obtained. Such a curve is a basis for theoretical models describing the deformation of elastic, isotropic material by a rigid, axisymmetric indenter such as the widely used Hertz-Sneddon contact mechanics. The Hertzian contact mechanics yields the following relation for the force, $F$, versus indentation depth, $\delta$, for a spherical indentation geometry (radius $R$ ) probing a homogeneous elastic medium:

$$
F=\frac{4}{3} \frac{E \sqrt{R}}{1-v^{2}} \delta^{3 / 2}
$$

where $E$ is the material's Young's modulus and $v$ is the Poisson ratio. Here, it is assumed that the Young's modulus of the indenter is much larger than the material probed. Overview of the impact of indentation geometries and elaborations of the theoretical basis for analysis of nanoscale mechanics has been provided [63], and also, more recently, summarizing, e.g., operation in dynamic modes [64]. Here we have chosen to focus on applying AFM to characterize aqueous microgels, including also samples made of polyelectrolytes [65-70]. AFM stands apart from most methods for determining the mechanical properties of microgels since it offers information at the nanoscale. Several studies have used AFM to directly measure the properties of individual microgel particles, focusing on the impact of their internal structure [61,71-73]. Mechanical properties of microgels depend on many parameters, which generally can be grouped into external factors and internal parameters associated with synthesis conditions. Temperature, $\mathrm{pH}$ and solvent composition have been identified as important external factors affecting the mechanical properties of microgels [74,75]. In Table 3, selected examples of the application of AFM for the determination of mechanical properties of microgels are summarized.

Results reported on the widely studied microgels made of poly ( $\mathrm{N}$-isopropylacrylamide) (PNIPAM) are included as an example of a material displaying inherent responsive character to various external stimuli [26]. AFM studies demonstrated that the crosslinker affects the swelling behavior and elastic properties of PNIPAM microgels [74]. With the increasing amount of crosslinker, the microgel ability to shrink decreases during the heating and cooling processes. The height/width ratio of individual microgel particles was preserved for high crosslinker concentrations, while at the low concentrations, the shrinking and swelling was accompanied by changes in microgel height. Moreover, the center of the microgel became more rigid with increasing crosslinker concentration and temperature. In another report, the mechanical properties of PNIPAM microgels were determined as a function of the crosslinkmonomer ratio [61]. Alongside the observed increased rigidity of the microgels as the ratio became higher, it was possible to obtain a radial distribution of mechanical properties. The microgels' core was stiffer (17 to $50 \mathrm{kPa}$ ) than its peripheral ( 3 to $40 \mathrm{kPa}$ ) parts, which was a difference elucidated for regions of the microgels in order of tens of $\mathrm{nm}$ apart. 
Table 3. Examples of determination of microgel mechanical properties determined by AFM *

\begin{tabular}{|c|c|c|c|c|c|}
\hline Microgel Properties & Immobilization & Cantilever & AFM Mode & $\begin{array}{l}\text { Shear or Young's } \\
\text { Modulus }\end{array}$ & Ref. \\
\hline $\begin{array}{c}\text { PNIPAm at } \mathrm{c}_{\mathrm{p}} \\
18.2 \mathrm{mg} / \mathrm{mL}-21.8 \mathrm{mg} / \mathrm{mL} \\
\text { crosslinked with BIS }\end{array}$ & $\begin{array}{l}\text { Adsorption on silicon } \\
\text { substrate }\end{array}$ & $\begin{array}{l}\text { MLCT-Bio-DC } \\
0.01 \mathrm{~N} / \mathrm{m} \\
0.03 \mathrm{~N} / \mathrm{m} \\
\text { pyramid }\end{array}$ & $\begin{array}{c}\text { FV; } \\
\text { PF-QNM }\end{array}$ & $\begin{array}{c}3-32 \mathrm{kPa} \\
17-48 \mathrm{kPa}\end{array}$ & [61] \\
\hline $\begin{array}{c}\text { Sodium alginate at } c_{p} 0.9-1.7 \% \text {, } \\
\text { crosslinked with Ca or Ba ions; size } \\
\text { range } 425-870 \mu \mathrm{m} \\
\text { (PNIPAM-co- }\end{array}$ & Micropatterned grid & $\begin{array}{l}\text { MLCT } \\
0.03 \mathrm{~N} / \mathrm{m}-0.1 \mathrm{~N} / \mathrm{m} \\
\text { pyramid }\end{array}$ & FV & $0.4-14.4 \mathrm{kPa}$ & {$[65]$} \\
\hline $\begin{array}{c}\text { PMAA/PDADMAC) } 9 / \text { PNIPAM- } \\
\text { co-PMAA }{ }^{\text {b }} c_{p}=12 \text { mmol, } \\
\text { crosslinked with BIS. Size range } \\
200-1400 \mathrm{~nm}\end{array}$ & $\begin{array}{l}\text { Adsorption: APTES } \\
\text { coated silicon }\end{array}$ & $\begin{array}{l}\text { SNML } \\
0.07 \mathrm{~N} / \mathrm{m} \\
\text { pyramid }\end{array}$ & PF-QNM & $\begin{array}{l}75 \mathrm{kPa} \text { at } 25^{\circ} \mathrm{C} \\
450 \mathrm{kPa} \text { at } 40^{\circ} \mathrm{C}\end{array}$ & [70] \\
\hline $\begin{array}{l}\text { PNIPAm-co-Aac at } c_{p} 3.7 \% \text { and } \\
5.4 \% \text {, crosslinked with BIS, size } \\
\text { range } 280-480 \mathrm{~nm}\end{array}$ & $\begin{array}{l}\text { Adsorption on } \mathrm{Au} \\
\text { coated silicon }\end{array}$ & $\begin{array}{c}\mathrm{HQ}: \mathrm{CSC} 38 / \mathrm{NO} \mathrm{AL} \\
0.05 \mathrm{~N} / \mathrm{m} \\
\text { cone }\end{array}$ & Microrheology & $100 \mathrm{kPa}-800 \mathrm{kPa}$ & [72] \\
\hline $\begin{array}{l}\text { PNIPAm at cp } 1.14 \% \text { crosslinked } \\
\text { either with } 2.5 \text { or } 10 \mathrm{~mol} \% \text { BIS. Size } \\
\text { of microgels } \sim 1000 \mathrm{~nm}\end{array}$ & $\begin{array}{l}\text { Adsorption on } \mathrm{Au} \\
\text { coated silicon }\end{array}$ & $\begin{array}{l}\text { AR-iDrive-N01 } \\
0.09 \mathrm{~N} / \mathrm{m} \\
\text { pyramid }\end{array}$ & FV & $\begin{array}{c}1-4 \mathrm{kPa} \text { (for } 2 \% \mathrm{BIS}) \\
6-40 \mathrm{kPa} \text { (for } 10 \% \\
\text { BIS) }\end{array}$ & [74] \\
\hline MMA; size of the order $\sim 100 \mathrm{~nm}$ & $\begin{array}{l}\text { GOPS coated } \\
\text { borosilicate }\end{array}$ & $\begin{array}{l}\text { ScanAsyst-Fluid } \\
0.4-0.7 \mathrm{~N} / \mathrm{m} \\
\text { pyramid }\end{array}$ & PF-QNM & $\begin{array}{l}\text { qualitative- } \\
\text { deformation } \\
\text { images }\end{array}$ & [75] \\
\hline $\begin{array}{c}\text { Alginate microspheres (UPLVG, } \\
\text { FMC) at } \\
c_{\mathrm{p}}=1.5 \% \text { crosslinked with Ca. Size } \\
\text { larger } \\
\text { than } 100 \mu \mathrm{m}\end{array}$ & $\begin{array}{l}\text { Deposition on nylon } \\
\text { mesh; } 330 \mu \mathrm{m} \text { holes; } \\
\text { glued to Petri dish }\end{array}$ & $\begin{array}{l}\text { PNP- TR } \\
0.32 \mathrm{~N} / \mathrm{m} \\
\text { pyramid }\end{array}$ & $\begin{array}{c}\text { QI, scan size } 3 \mu \mathrm{m} \times \\
3 \mu \mathrm{m}\end{array}$ & up to $8.75 \mathrm{MPa}$ & [76] \\
\hline $\begin{array}{c}\text { Alginate microspheres (UPLVG, } \\
\text { FMC) at } \\
c_{p}=1.5 \% \text { crosslinked with genipin. } \\
\text { Size larger than } 100 \mu \mathrm{m}\end{array}$ & $\begin{array}{l}\text { Deposition on nylon } \\
\text { mesh; } 330 \mu \text { m holes; } \\
\text { glued to Petri dish }\end{array}$ & $\begin{array}{l}\text { PNP-TR } \\
0.32 \mathrm{~N} / \mathrm{m} \\
\text { pyramid }\end{array}$ & $\begin{array}{c}\text { QI, scan size } 3 \mu \mathrm{m} \times \\
3 \mu \mathrm{m}\end{array}$ & up to $3.67 \mathrm{MPa}$ & [76] \\
\hline $\begin{array}{l}\text { PNIPAm crosslinked with BIS; size } \\
\text { of microgels } 150-350 \mathrm{~nm}\end{array}$ & $\begin{array}{l}\text { Adsorption: APTES } \\
\text { coated silicon }\end{array}$ & $\begin{array}{l}\text { MLCT-BIO-DC } \\
0.03 \mathrm{~N} / \mathrm{m} \\
\text { pyramid }\end{array}$ & QI & $16-140 \mathrm{~N} / \mathrm{m}$ & {$[8,77]$} \\
\hline $\begin{array}{c}\text { Polyacrylamide (PAAm) } 5.9 \% \text { to } \\
11.8 \% \\
\text { Crosslinked with BIS; size of } \\
\text { microgels } 13.3-18.0 \mu \mathrm{m}\end{array}$ & $\begin{array}{l}\text { Plasma cleaned } \\
\text { silicon }\end{array}$ & $\begin{array}{l}\text { MLCT } 0.03 \mathrm{~N} / \mathrm{m} \\
\text { pyramid }\end{array}$ & $\mathrm{FV}$ & $0.09-11 \mathrm{kPa}$ & [17][ \\
\hline $\begin{array}{l}\text { PAAm functionalized with NHS } \\
\text { (N-succinimidyl ester) } 7.9 \% \text {, } \\
\text { crosslinked with BIS- }\end{array}$ & $\begin{array}{l}\text { Plasma cleaned } \\
\text { silicon }\end{array}$ & $\begin{array}{l}\text { MLCT } \\
0.03 \mathrm{~N} / \mathrm{m} \\
\text { pyramid }\end{array}$ & FV & $1.6 \mathrm{kPa}$ & [17] \\
\hline $\begin{array}{l}\text { pS-co-NIPAM, } 50 \% \text { to } 70 \% \\
\text { crosslinked with BIS (0-3 mol\%); } \\
\text { size of microgels } 220-627 \mathrm{~nm} ;\end{array}$ & Not specified & $\begin{array}{l}\text { silicon nitride } \\
0.2-0.8 \mathrm{~N} / \mathrm{m}\end{array}$ & $\mathrm{FV}$ & $0.24-0.99 \mathrm{GPa}$ & [78] \\
\hline $\begin{array}{l}\text { ULC microgels-PNIPAm } 146 \mathrm{mM} \\
\text { Crosslinked with BIS; size range of } \\
\text { microgels } 1.1 \pm 0.1 \mu \mathrm{m}\end{array}$ & $\begin{array}{l}\text { Adsorption on } \\
\text { APTES coated glass }\end{array}$ & $\begin{array}{l}\text { silicon nitride } \\
0.09 \mathrm{~N} / \mathrm{m} \\
\text { sphere }\end{array}$ & FV & $\sim 10 \mathrm{kPa}$ & {$[12,79]$} \\
\hline $\begin{array}{l}\text { Covalently crosslinked hyaluronic } \\
\text { acid-based microgels fabricated } \\
\text { using microfluidics. Size: } 73-91 \mu \mathrm{m} \\
\text { depending on crosslinker and } c_{\mathrm{p}}\end{array}$ & $\begin{array}{l}\text { Adsorption on PEI } \\
\text { imine coated, plasma } \\
\text { cleaned glass }\end{array}$ & $\begin{array}{l}\text { CSC38 } \\
0.09 \mathrm{~N} / \mathrm{m} \\
\text { tipless }\end{array}$ & Force-distance & $\begin{array}{l}\mathrm{E} \text { from } 11 \text { to } 34 \mathrm{kPa} \\
\text { depending on sample }\end{array}$ & [20] \\
\hline
\end{tabular}

* Abbreviations used in the table: PNIPAm-poly(N-isopropylacrylamide); pS-co-NIPAM-poly(styrene-co- $N$-isopropylacrylamide); PVCL-poly(N-vinylcaprolactam; TBCHA-4-tert-butylcyclohexyl acrylate; co-PMAA—co-methacrylic acid; PDADMAC-poly(diallyldimethylammonium chloride); PEG-PLPs-oligo ethylene glycol methacrylates with 4-5 ethyleneoxide repeating units and methacrylic acid; MMA - methacrylic acid; APTES-3-aminopropyl)triethoxysilane; GOPS-3-glycidoxypropyltrimethoxysilane; PBSphosphate buffered saline; $\mathrm{PAH}$ - poly(allylamine hydrochloride); BIS— $N, N^{\prime}$-methylene-bis-acrylamide; AAc—acrylic acid; FV—force volume; PF-QNM—-peak force quantitative nanomechanics; QI—quantitative imaging; PNIPAM-co-PMAA microgel/PDADMAC multilayer films.

Moreover, highly crosslinked microgels seem to be more homogenous in terms of mechanical properties. The microgels are sensitive to temperature. The AFM-based elasticity measurements, conducted on P(NIPAM-co-AAc) microgels, show temperature-dependent microgels' response (their shrinking) in an aqueous solution above their volume phase transition temperature (VPTT). Using various mixtures of two good PNIPAM solvents, i.e., water and ethanol, demonstrated that the interaction between polymer and solvent affected the rheological properties of microgels [72]. An interesting example of the AFM 
measurements are microgels whose swelling is governed by electrostatic interactions. The peak-force quantitative nano-mechanics (PF-QNM) measurement mode applied to poly(ethyl acrylate-co-methacrylic acid) microgels revealed that the mechanical properties depend on the available fraction of charged groups present within the microgels, related to charge density. Interestingly, the microgels of intermediate charge densities were more deformable [75]. In one of the early studies, the mechanical properties of hydrogels' microspheres were measured to estimate the resistance to compression affected by chemical composition [65]. The results show that all alginate-based hydrogels exhibited pure elastic behavior with elastic (Young's) modulus ranging from 0.4 to $440 \mathrm{kPa}$. Microspheres containing $\mathrm{BaCl}_{2}$ appeared to be softer than those containing $\mathrm{CaCl}_{2}$. In more recent studies, the coating of alginate microspheres with genipin-crosslinked double poly-L-lysine (PLL) results in a tighter organization of poly-L-lysine crosslinked by genipin [76]. More advanced AFM working modes such as the high-speed AFM (HS-AFM) can also be involved in the characterization of microgels. In one example [80], HS-AFM was applied to study the real-time adsorption of various types of microgels to verify the hypothesis that the microgels' deformability affects the adsorption's kinetics to a solid surface in aqueous conditions. Results show that more deformable microspheres adsorb faster than more rigid ones, thus, showing the possibility to design microgels characterized by the specific adsorption properties.

Overall, these examples from the application of AFM for the determination of mechanical properties of microgels highlight that rich, microgel-specific signatures can be obtained. Furthermore, related to a more practical side in performing such experiments is the variety of immobilization strategies employed, which can serve as a source of inspiration when embarking on new samples.

\section{Micropipette Aspiration for Microgel Mechanical Characterization}

In the micropipette aspiration technique, a micropipette is brought in contact with the surface of the deformable object, and a small suction pressure applied through the micropipette is generating the stress field leading to the suction of the soft material into the pipette (Figure 1a), which is typically determined using conventional optical microscopy. Combining the experimental data of applied pressure difference and suction length with the appropriate material model yields an estimate of the mechanical properties. Thus, the suction of a soft material modeled as homogeneous in half-space yields the following relation between the pressure difference $\Delta p$ and aspiration length at the central micropipette symmetry axis, $L_{\mathrm{p}}[81]$ :

$$
\Delta p=\frac{2 \pi E L_{p}}{3 R_{p}} \Phi
$$

where $E$ is Young's modulus, $R_{\mathrm{p}}$ is the micropipette radius and $\Phi$ is the wall function determined by the geometry of the pipette, and a value of $\Phi=2.0-2.1$ [82] is commonly used. Zhou and coworkers extended the analysis of the mechanically homogeneous case to micropipette suction of spherical reference state using a finite element approach [83]. Within a range of pipette radii relative to the radius of the spherical reference state, $R_{\mathrm{C}}$, they provided the based on non-linear regression to the FEM results: following empirical relation

$$
\Delta p=\frac{E}{3} \frac{L}{R_{p}}\left[\beta_{1}+\beta_{2} \frac{L}{R_{p}}\right]\left[1-\left(\frac{R_{p}}{R_{c}}\right)^{\beta_{3}+\beta_{4} \frac{L}{R_{p}}+\beta_{5}\left(\frac{L}{R_{p}}\right)^{2}}\right]
$$

where the coefficients were $\beta_{1}=2.0142, \beta_{2}=2.1186, \beta_{3}=2.1187, \beta_{4}=-1.4409$ and $\beta_{5}=0.3154$. Thus, the basis for the analysis of the pressure-aspiration length profile will yield an estimate of Young's modulus that is less for the half-plane theoretical expression than that based on the suction of the spherical bead, and the deviation becomes larger, the smaller the $R_{\mathrm{c}} / R_{\mathrm{p}}$. 
The micropipette aspiration technique has also been extended to map dynamic properties applying a cyclic pressure gradient [12]:

$$
p(t)=p_{0} \sin \left(\omega t+\theta_{P}\right)+\text { cons } t
$$

and determining the resulting aspired length change:

$$
L(t)=L_{0} \sin \left(\omega t+\theta_{L}\right)+\text { const }
$$

Following standard approaches in periodic loading experiments, the dynamic storage, $E^{\prime}$, and loss, E", moduli were determined from the amplitudes and phases:

$$
\begin{aligned}
& E^{\prime}=\frac{3 R_{p} \Phi p_{0}}{2 \pi L_{0}} \cos (\Delta \theta) \\
& E^{\prime \prime}=\frac{3 R_{p} \Phi p}{2 \pi L_{0}} \sin (\Delta \theta)
\end{aligned}
$$

where $\Delta \theta$ is the phase difference $\Delta \theta=\theta_{\mathrm{P}}-\theta_{\mathrm{L}}$ between the phases of the applied pressure and resulting aspired length, $p_{0}$ and $L_{0}$ are the amplitude of the cyclic aspiration pressure and length, and $\omega$ is the frequency.

Examples of mechanical data reported for microgels employing micropipette aspiration strategies include determining Young's moduli of gelatin microgels of various sizes as gelled in a confined space made of liposomes [84]. They reported an increase in $E$ when the radius of the microgels was less than $\sim 40-50 \mu \mathrm{m}$, and combined with other characterization tools interpreted the increased elasticity in view of differences in the extent of higher-order structures existing in the droplet approach as compared to the bulk state. Thus, the increased amount of $\beta$-sheet in the microgels, suggested to be due to a confinement effect, was suggested to be the structural basis for the increased elastic modulus. The extension to determine dynamic elastic properties of microgels, also in the case of gelatin, resulted in the identification of both an increased storage modulus and decreased loss modulus of the material in the microgel form as compared to the bulk state. Stöver et al. [85] employed micropipette aspiration to determine mechanical properties of Ca-alginate hydrogel beads, their subsequent coating with polycation layer and treatment of resulting structures with citrate to reduce the extent of $\mathrm{Ca}^{2+}$ mediated crosslinking of alginate in the core. Examples of results obtained include reduced $E$ as a function of extended storage of the alginate microgels, and changes in apparent Young's modulus associated with the transformation of initial alginate microgel bead to a capsule, with a more viscous core. In this approach, the theoretical assumption of a homogeneous elastic body being interrogated by the micropipette aspiration strategy underpins the reported data.

While examples of micropipette aspiration to determine mechanical properties of microgels highlight the possibility to extract information identifying specific features related to microgels, such as confinement and impact of transformation from a microgel bead to a capsule, there appears to be potential for improvements in the approaches. This includes the application of results such as explicit consideration of the deformed object being spherical in its reference state and more realistic distributions of mechanical properties.

\section{High-Throughput Microgel Mechanics' Determination in Microchannels}

While the methods presented above currently represent core tools in assessing mechanical properties of microgels, scanning probe and micropipette aspiration are generally considered as not being ideal for rapid characterization of a large number of microgels at the individual object level. Thus, techniques based on feeding microgel objects in devices, subjecting them to mechanical characterization mimicking strategies in flow cytometers, have been developed. Techniques exploiting squeezing of microgels in tapered microchan- 
nels, forcing them through constrictions or exposing the soft entities to fluid shear stress or elongational stress, one at a time, have been reported. In the case of microgels passing through constrictive microfluidic channels, several analytical mechanical models have been proposed [86-88] to define relations between the measured pressure, the radius ratio of the elastic sphere to the channel and the global elastic property of the microgels, thus underpinning the analysis of experimental observations. These models are limited to microfluidic channels with a diameter smaller than an unperturbed microgel size. In one example, the deformable microgels are fed into a tapered microchannel. When transported into increasingly narrower parts by a liquid flow, the microgels will eventually block the channel for the liquid to pass, resulting in a situation where the elastic deformation of the microgel will balance the pressure difference. However, the modes proposed by $[86,87]$ cannot be applied to high- throughput techniques.

Forcing soft entities through even microchannels with cross-section less than the crosssectional area was introduced to determine mechanical features of cancer cells (constrictionbased deformability cytometry, cDC) [89], and can also be applied for the determination of microgels. In this approach, the passage time through a given length of the constriction is used as an indicator of mechanical properties [90,91]. Other approaches include deformation induced in the stagnation point in opposing channels in devices supporting elongational flow (extensional deformation cytometry, xDC) [92]. In this case, the mechanical signature is estimated as the ratio of the long and short axis of the deformed object as determined by optical imaging. Shear stress induced in a constricted channel, but with a cross-section larger than the object to be deformed (shear deformation cytometry, sDC) is a third approach to high-throughput characterization applicable for microgels. In their report, Mietke and coworkers used a deformability parameter extracted from images captured by a high-speed camera and combined this with analysis of the deformation of mechanically homogeneous objects as well as structures with a shell [93].

These toolboxes underpinning real-time measurements of microgel deformation provide high-throughput at different rates, and impose stress at different rates [94]. The awareness of the latter differences is important when comparing different tools to determine the moduli since the materials may have intrinsic frequency dependent properties. The development of these deformability cytometry (DC) tools, originally intended for the characterization of cells, has also migrated to the measurements of microgels. More recent advancement of the technique includes modes such as real-time-DC (RT-DC), quantitativeDC, or dynamic RT-DC (dRT-DC) [17,95]. Spherical PNIPAM microgels with two different crosslinking densities characterized by such DC techniques were found to produce egg-like to triangular-shaped deformed states at a shear rate of $163 \mathrm{~s}^{-1}$, which was deformed further to parachute-like structures at $326 \mathrm{~s}^{-1}$ for the specimen with $0.15 \mathrm{wt} \%$ crosslinker. The focus was on the changing capillary number on the deformation behavior of microgels at two different crosslinker concentrations. The specimens in this study were generated using a flow-focusing strategy realized by a microfluidic device, ensuring a relative standard deviation of $7.7 \%$ of the $249 \mu \mathrm{m}$ diameter microgels. While the highly desirable, nearly monodisperse character of microgels subjected to DC and RT-DC characterization was realized in this study, the actual microgel sizes were larger than that of cellular structures. Although not being a polyelectrolyte hydrogel, the previous example, and the reported RT-DC determination of polyacrylamide hydrogels with a diameter less than $20 \mu \mathrm{m}$ [17] illustrate features of this technique. In their report, Guck and coworkers [17] prepared polyacrylamide (PAA) microgels being close to $12 \mu \mathrm{m}$ diameter and nearly independent of monomer concentration in oil (all with relative standard deviation in the interval 5.6 to $8.3 \%$ ) before being transferred and equilibrated in aqueous solution. The PAA microgels increased in size, dependent on the composition following equilibration in an aqueous solution. The RT-DC measurement yielded Young's moduli for the microgels of mean value in the range $1.2 \mathrm{kPa}$ to $1.6 \mathrm{kPa}$ for different batches of the sample with $7.9 \%$ polymer concentration, and a relative standard deviation of Young's modulus between 11 and 21\%. While the authors reported overlaps in the range of $E$ determined with RT-DC and AFM, it 
is interesting to note that the relative standard deviation of the microgels determined by AFM in the range $23-51 \%$ is larger than observed when using RT-DC. Another noteworthy feature reported in this study is the relaxation time of $0.12 \pm 0.02 \mathrm{~ms}$ for the deformation of the microgels, a parameter that was deduced from the analysis of images of deformed states along the channel. A further example of RT-DC applied to microgels is the analysis of covalent crosslinked hyaluronic acid (HA) microgels aided by flow focusing in obtaining nearly monodisperse microgel samples, with a mean diameter in the range 24 to $30 \mu \mathrm{m}$, depending on actual HA modification and crosslinking chemistry, as equilibrated in phosphate-buffered saline [18]. The RT-DC provide distributions of the mechanical properties (Figure 2) that show a mean value of Young's modulus that increases with increasing crosslinking density and depends on the derivatization strategy. Moreover, the heat-plots also indicate that the smaller fractions of the hydrogel samples have a significantly larger Young's modulus than the main trend within the sample. This indicated that the technique might serve as a viable strategy to determine subfractions with altered mechanical properties in a label-free strategy.
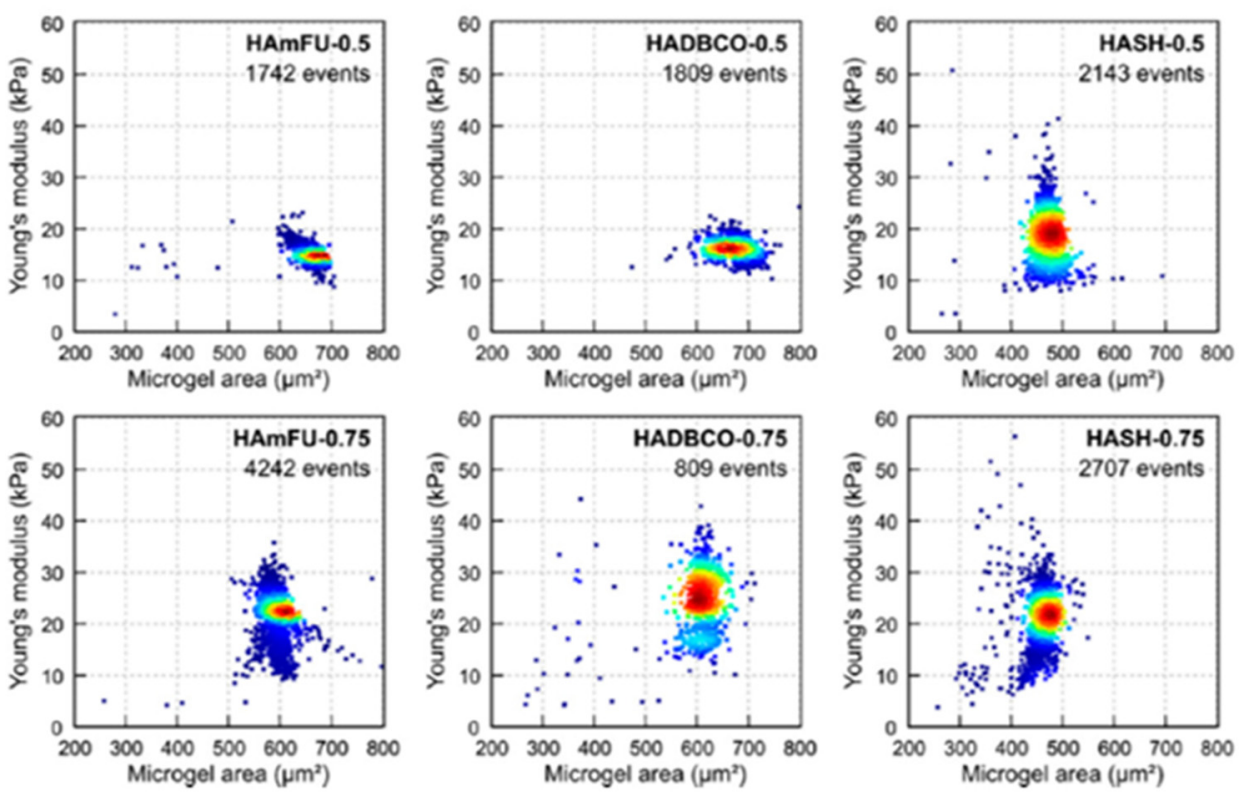

Figure 2. Scatter plots of mechanical properties of various hyaluronic acid derivative microgels determined by RT-DC. The intensity maps of Young's modulus versus cross-sectional area of the microgels are shown for three different types of HA derivative microgels, each at two concentrations of PEG-based crosslinker. The RT-DC characterization was reported for characterization of in a microfluidic channel with $40 \times 40 \mu \mathrm{m}^{2}$ cross-section and $300 \mu \mathrm{m}$ long using a flow rate of $0.60 \mu \mathrm{L}$ $\mathrm{s}^{-1}[18]$.

In many of the approaches overviewed above, analysis strategies routed in analytical models are used as a starting point for, e.g., the real-time classifications of soft objects. These analytical models neglect the interaction between the deformed body shapes and changes in the surrounding hydrodynamic flow profiles. Various research has demonstrated that analysis of mechanical properties of cells results in large variability of two main origins, namely, biological variability and technical inaccuracy. The use of microgels as the mechanical and geometric model of the cells allows for the development of protocols related to measurements, data analysis and interpretation to be applied to cells. Recently, numerical models that can account for the interaction between the fluid and deformable cells in microfluidic devices have been developed to interpret the results of high-throughput experiments. These numerical models show good potential for cell stiffness assessment from high-throughput microfluidic devices as they can account for various channel geometries and flow conditions. Belotti et al. [96] presented a fully-coupled time- dependent 
fluid-structure interaction (FSI) finite element model of a hydrodynamic stretcher using COMSOL Multiphysics. Saadat et al. [97] reported an immersed boundary (IB) method to model red blood cells moving in microfluidic constriction larger than the cells. Mokbel et al. [98] reported a grid-based FSI model implemented in ADMis [99] applied to eukaryotic cells in microfluidic constriction larger than the cell.

While the examples summarize both the microgel and cellular specimens, the highthroughput strategies often employ the characterization of microgel beads for calibration that enables the classification of the measured cells. The simultaneous use of many channels to analyze deformations of breast and pancreatic cancer cells of different metastatic potential revealed that the higher metastatic potential of breast cancer cells correlates to higher deformations. In contrast, pancreatic cells revealed the opposite behavior [100]. Recent studies have shown that Fourier analysis of cellular-shape modes allows disentangling the cell response to time-dependent and time-independent hydrodynamic stress distributions [95]. These examples underline the usefulness and applicability of microgels in developing biorheological/biomechanical-based methods to analyze the properties of pathologically or functionally altered cells.

\section{Local Microgel Deformation by Optical Techniques}

Various optical strategies beyond those integrated, e.g., for image acquisition, have also been discussed for application to determine mechanical properties of microgels. Application of molecular rulers functionalized with donor-acceptor fluorophore pairs supporting Förster resonance energy transfer (FRET) is an emerging strategy that has been applied for reporting changes in proximity between various entities, in particular, associated with cell adhesion [101], but also included as molecular reporters of changes in local deformation in microgels [102]. The fact that FRET provides information on the proximity within the donor-acceptor pair calls for calibration to transform the signal to mechanical stress. In this perspective, Thiele and coworkers combined AFM with confocal microscopy to apply a local, controlled force and observe the resulting change in the FRET signatures [102]. Thus, the local acceptor/donor intensity ratio was found to increase in the region adjacent to the contact area of the AFM-indented region, thus indicating that also local features (limited by the resolution in the employed microscope) can be determined.

Thiele and coworkers [20] reported Brillouin shifts of hyaluronan derivatives' microgels and found that the crosslinked microgel using a longer chain length of the bifunctional crosslinker yielded a larger Brillouin shift. This difference was stated to be parallel to trends in Young's modulus observed by indentation of the same specimens. The Brillouin light scattering is a noncontact imaging technique that does not require contrast agents or labeling [103]. The probing mechanism involves the coupling of photons to longitudinal phonons and the obtained scattering spectra can be interpreted as the response of the sample to an infinitesimal uniaxial compression, and formally described by the longitudinal modulus (i.e., the compressional stiffness). The reported data by Thiele and coworkers on the Brillouin shifts [20] that can be translated to longitudinal moduli are considered interesting to gain more experience on the applicability of this tool to microgels, e.g., soft materials with a dominating fraction of water, for which the particular signal has been discussed [104,105].

\section{Conclusions}

A range of various approaches has been applied to determine the mechanical properties of microgels, including also those synthesized using polyelectrolytes. Although numerous interesting facets have been reported, the three main issues of awareness for work in this field appear evident. The first is related to the fact that differences in the rate of deformation/stress exposure which are not always explicit in the literature, may lead to difficulties in comparing results obtained using different strategies. Using standard theory for the frequency dependence of mechanical properties of polymers also in the crosslinked, stated as in microgels (e.g., [106]) as inspiration, differences in moduli at dif- 
ferent frequencies are expected. Secondly, the impression that different levels of refinement of theoretical description are used to extract material parameters from the imposed and observable parameters is a further complication when comparing different approaches. A third facet to be aware of is the possible difference in mechanical properties of the microgels as compared to the bulk state of the same constituents.

The mechanical properties in the macroscale rarely overlap with those measured on the nanoscale. This highlights the need to find and unravel the relation between microgels' formation and/or surface functionalization with the structure, shape and mechanical properties. Understanding how mechanical properties of microgels vary at different length scales, and in response to the type of the solvent, composition and the presence of divalent ions, is of great importance in some mechanical properties of cells. Detailed characterization of microgels prepared with controlled constituents may therefore also serve as a route to understand changes in mechanical properties of cells. Microgels can model cell shape and mechanical properties. Understanding how these properties change is particularly significant in controlling, regulating and functioning of the cells. Biomechanical properties change during cancer progression. Cells became more deformable, as has been shown by AFM measurements conducted for various cancers, including bladder [107], lung, cervical and breast cancers [62].

Alterations of mechanical properties are not exclusively observed for cancer cells. Moreover, normal cells change their mechanics in response to altered conditions of the surrounding microenvironment. For example, endothelial cells exposed to chronic hyperglycemia [108] adapts their mechanical properties leading to dysfunction of the endothelium [109]. In simpler cells such as bacteria, the wall elastic properties have been demonstrated to have beneficial effects on probiotic bacteria strains. Bacteria with more deformable wall possess higher resistance to intracellular digestion by macrophages and a higher level of their activation [110]. Furthermore, microgels might be applied to mimic cell-cell interactions in a controlled microenvironment if isolated cell surface receptors (or their active parts) and the corresponding ligands can be embedded within the microgel surface. This will emulate the biological, biochemical and biophysical properties of the native cellular microenvironment and allow to disentangle the contribution of specific receptor types in the overall adhesive properties of cells. Thus, better identification of essential cues involved in pathological processes will be achievable. Future research opens the way for biochemical and biophysical modifications of microgels, which will improve the way of mimicking the extracellular matrix, thus enabling to detection or control of the cellular response in the altered surrounding microenvironment.

Author Contributions: Conceptualization, B.T.S.; writing—original draft preparation, all authors; writing-review and editing, all authors; project administration and funding acquisition, M.L. and B.T.S. All authors have read and agreed to the published version of the manuscript.

Funding: This work was supported by the Norwegian Financial Mechanism for 2014-2021, National Science Center (Poland), project no. UMO-2019/34/H/ST3/00526 (GRIEG).

Acknowledgments: The authors gratefully acknowledge the support from National Science Center, Krakow, Poland.

Conflicts of Interest: The authors declare no conflict of interest.

\section{References}

1. Shibayama, M. Spatial inhomogeneity and dynamic fluctuaions of polymer gels. Macromol. Chem. Phys. 1998, 199, 1-30. [CrossRef]

2. Zhang, L.; Chen, K.; Zhang, H.; Pang, B.; Choi, C.-H.; Mao, A.S.; Liao, H.; Utech, S.; Mooney, D.J.; Wang, H.; et al. Microfluidic Templated Multicompartment Microgels for 3D Encapsulation and Pairing of Single Cells. Small 2018, 14, 1702955. [CrossRef] [PubMed]

3. Olesen, M.T.J.; Winther, A.K.; Fejerskov, B.; Dagnaes-Hansen, F.; Simonsen, U.; Zelikin, A.N. Bi-Enzymatic Embolization Beads for Two-Armed Enzyme-Prodrug Therapy. Adv. Ther. 2018, 1, 1800023. [CrossRef] 
4. Kamperman, T.; Karperien, M.; Le Gac, S.; Leijten, J. Single-Cell Microgels: Technology, Challenges, and Applications. Trends Biotechnol. 2018, 36, 850-865. [CrossRef]

5. Fenton, O.S.; Olafson, K.N.; Pillai, P.S.; Mitchell, M.J.; Langer, R. Advances in Biomaterials for Drug Delivery. Adv. Mater. 2018, 30, 1705328. [CrossRef] [PubMed]

6. Andablo-Reyes, E.; Yerani, D.; Fu, M.; Liamas, E.; Connell, S.; Torres, O.; Sarkar, A. Microgels as viscosity modifiers influence lubrication performance of continuum. Soft Matter 2019, 15, 9614-9624. [CrossRef]

7. LeBlanc, K.J.; Niemi, S.R.; Bennett, A.I.; Harris, K.L.; Schulze, K.D.; Sawyer, W.G.; Taylor, C.; Angelini, T.E. Stability of High Speed 3D Printing in Liquid-Like Solids. ACS Biomater. Sci. Eng. 2016, 2, 1796-1799. [CrossRef] [PubMed]

8. O’Bryan, C.S.; Kabb, C.P.; Sumerlin, B.S.; Angelini, T.E. Jammed Polyelectrolyte Microgels for 3D Cell Culture Applications: Rheological Behavior with Added Salts. ACS Appl. Bio Mater. 2019, 2, 1509-1517. [CrossRef]

9. Isapour, G.; Lattuada, M. Bioinspired Stimuli-Responsive Color-Changing Systems. Adv. Mater. 2018, 30, 1707069. [CrossRef] [PubMed]

10. Zhao, S.; Pu, W.F. Migration and plugging of polymer microspheres (PMs) in porous media for enhanced oil recovery: Experimental studies and empirical correlations. Colloids Surf. A Physicochem. Eng. Asp. 2020, 597. [CrossRef]

11. González-Bermúdez, B.; Guinea, G.V.; Plaza, G.R. Advances in Micropipette Aspiration: Applications in Cell Biomechanics, Models, and Extended Studies. Biophys. J. 2019, 116, 587-594. [CrossRef]

12. Sakai, A.; Murayama, Y.; Yanagisawa, M. Cyclic Micropipette Aspiration Reveals Viscoelastic Change of a Gelatin Microgel Prepared Inside a Lipid Droplet. Langmuir 2020, 36, 5186-5191. [CrossRef] [PubMed]

13. Guck, J.; Schinkinger, S.; Lincoln, B.; Wottawah, F.; Ebert, S.; Romeyke, M.; Lenz, D.; Erickson, H.M.; Ananthakrishnan, R.; Mitchell, D.; et al. Optical Deformability as an Inherent Cell Marker for Testing Malignant Transformation and Metastatic Competence. Biophys. J. 2005, 88, 3689-3698. [CrossRef]

14. Lekka, M. Discrimination Between Normal and Cancerous Cells Using AFM. Bionanoscience 2016, 6, 65-80. [CrossRef] [PubMed]

15. Zhou, G.Q.; Zhang, B.K.; Tang, G.L.; Yu, X.F.; Galluzzi, M. Cells nanomechanics by atomic force microscopy: Focus on interactions at nanoscale. Adv. Phys. X 2021, 6. [CrossRef]

16. Krieg, M.; Fläschner, G.; Alsteens, D.; Gaub, B.M.; Roos, W.H.; Wuite, G.J.L.; Gaub, H.E.; Gerber, C.; Dufrêne, Y.F.; Müller, D.J. Atomic force microscopy-based mechanobiology. Nat. Rev. Phys. 2019, 1, 41-57. [CrossRef]

17. Girardo, S.; Träber, N.; Wagner, K.; Cojoc, G.; Herold, C.; Goswami, R.; Schlüßler, R.; Abuhattum, S.; Taubenberger, A.; Reichel, F.; et al. Standardized microgel beads as elastic cell mechanical probes. J. Mater. Chem. B 2018, 6, 6245-6261. [CrossRef]

18. Heida, T.; Otto, O.; Biedenweg, D.; Hauck, N.; Thiele, J. Microfluidic Fabrication of Click Chemistry-Mediated Hyaluronic Acid Microgels: A Bottom-Up Material Guide to Tailor a Microgel's Physicochemical and Mechanical Properties. Polymers 2020, 12, 1760. [CrossRef]

19. Distler, T.; Kretzschmar, L.; Schneidereit, D.; Girardo, S.; Goswami, R.; Friedrich, O.; Detsch, R.; Guck, J.; Boccaccini, A.R.; Budday, S. Mechanical properties of cell- and microgel bead-laden oxidized alginate-gelatin hydrogels. Biomater. Sci. 2021. [CrossRef]

20. Hauck, N.; Seixas, N.; Centeno, S.P.; Schluelsser, R.; Cojoc, G.; Mueller, P.; Guck, J.; Woell, D.; Wessjohann, L.A.; Thiele, J. DropletAssisted Microfluidic Fabrication and Characterization of Multifunctional Polysaccharide Microgels Formed by Multicomponent Reactions. Polymers 2018, 10, 1055. [CrossRef]

21. Aangenendt, F.J.; Mattsson, J.; Ellenbroek, W.G.; Wyss, H.M. Mechanics from Calorimetry: Probing the Elasticity of Responsive Hydrogels. Phys. Rev. Appl. 2017, 8, 014003. [CrossRef]

22. Rey, M.; Fernández-Rodríguez, M.Á.; Steinacher, M.; Scheidegger, L.; Geisel, K.; Richtering, W.; Squires, T.M.; Isa, L. Isostructural solid-solid phase transition in monolayers of soft core-shell particles at fluid interfaces: Structure and mechanics. Soft Matter 2016, 12, 3545-3557. [CrossRef] [PubMed]

23. Mattsson, J.; Wyss, H.M.; Fernandez-Nieves, A.; Miyazaki, K.; Hu, Z.; Reichman, D.R.; Weitz, D.A. Soft colloids make strong glasses. Nature 2009, 462, 83-86. [CrossRef]

24. Mauri, E.; Giannitelli, S.M.; Trombetta, M.; Rainer, A. Synthesis of Nanogels: Current Trends and Future Outlook. Gels 2021, 7, 36. [CrossRef]

25. Karg, M.; Pich, A.; Hellweg, T.; Hoare, T.; Lyon, L.A.; Crassous, J.J.; Suzuki, D.; Gumerov, R.A.; Schneider, S.; Potemkin, I.I.; et al. Nanogels and Microgels: From Model Colloids to Applications, Recent Developments, and Future Trends. Langmuir 2019, 35, 6231-6255. [CrossRef]

26. Nur, H.; Pinkrah, V.T.; Mitchell, J.C.; Benée, L.S.; Snowden, M.J. Synthesis and properties of polyelectrolyte microgel particles. Adv. Colloid Interface Sci. 2010, 158, 15-20. [CrossRef] [PubMed]

27. Brown, A.C.; Stabenfeldt, S.E.; Ahn, B.; Hannan, R.T.; Dhada, K.S.; Herman, E.S.; Stefanelli, V.; Guzzetta, N.; Alexeev, A.; Lam, W.A.; et al. Ultrasoft microgels displaying emergent platelet-like behaviours. Nat. Mater. 2014, 13, 1108-1114. [CrossRef]

28. Nguyen, V.N.; Huang, N.; Grossiord, J.-L.; Moine, L.; Agnely, F.; Vauthier, C. Rheological characterization of mechanical properties of chemically crosslinked microspheres. J. Appl. Polymer Sci. 2013, 128, 3113-3121. [CrossRef]

29. Merkel, T.J.; Jones, S.W.; Herlihy, K.P.; Kersey, F.R.; Shields, A.R.; Napier, M.; Luft, J.C.; Wu, H.; Zamboni, W.C.; Wang, A.Z.; et al. Using mechanobiological mimicry of red blood cells to extend circulation times of hydrogel microparticles. Proc. Natl. Acad. Sci. USA 2011, 108, 586-591. [CrossRef] [PubMed]

30. Hashmi, S.M.; Dufresne, E.R. Mechanical properties of individual microgel particles through the deswelling transition. Soft Matter 2009, 5, 3682-3688. [CrossRef] 
31. Douglas, A.M.; Fragkopoulos, A.A.; Gaines, M.K.; Lyon, L.A.; Fernandez-Nieves, A.; Barker, T.H. Dynamic assembly of ultrasoft colloidal networks enables cell invasion within restrictive fibrillar polymers. Proc. Natl. Acad. Sci. USA 2017, 114, 885-890. [CrossRef]

32. Verhulsel, M.; Vignes, M.; Descroix, S.; Malaquin, L.; Vignjevic, D.M.; Viovy, J.-L. A review of microfabrication and hydrogel engineering for micro-organs on chips. Biomaterials 2014, 35, 1816-1832. [CrossRef] [PubMed]

33. Bai, F.; Yang, X.; Huang, W. Preparation of narrow or monodisperse poly (ethyleneglycol dimethacrylate) microspheres by distillation-precipitation polymerization. Eur. Polymer J. 2006, 42, 2088-2097. [CrossRef]

34. Goh, E.C.C.; Stöver, H.D.H. Cross-Linked Poly (methacrylic acid-co-poly(ethylene oxide) methyl ether methacrylate) Microspheres and Microgels Prepared by Precipitation Polymerization: A Morphology Study. Macromolecules 2002, 35, 9983-9989. [CrossRef]

35. Zhou, W.; Stukel, J.M.; Cebull, H.L.; Willits, R.K. Tuning the Mechanical Properties of Poly (Ethylene Glycol) Microgel-Based Scaffolds to Increase 3D Schwann Cell Proliferation. Macromol. Biosci. 2016, 16, 535-544. [CrossRef]

36. Menut, P.; Seiffert, S.; Sprakel, J.; Weitz, D.A. Does size matter? Elasticity of compressed suspensions of colloidal- and granularscale microgels. Soft Matter 2012, 8, 156-164. [CrossRef]

37. Joshi, A.; Nandi, S.; Chester, D.; Brown, A.C.; Muller, M. Study of Poly (N-isopropylacrylamide-co-acrylic acid) (pNIPAM) Microgel Particle Induced Deformations of Tissue-Mimicking Phantom by Ultrasound Stimulation. Langmuir 2018, 34, 1457-1465. [CrossRef] [PubMed]

38. Milani, A.H.; Freemont, A.J.; Hoyland, J.A.; Adlam, D.J.; Saunders, B.R. Injectable Doubly Cross-Linked Microgels for Improving the Mechanical Properties of Degenerated Intervertebral Discs. Biomacromolecules 2012, 13, 2793-2801. [CrossRef] [PubMed]

39. Zhao, W.; Nugroho, R.W.N.; Odelius, K.; Edlund, U.; Zhao, C.; Albertsson, A.-C. In Situ Cross-Linking of Stimuli-Responsive Hemicellulose Microgels during Spray Drying. ACS Appl. Mater. Interfaces 2015, 7, 4202-4215. [CrossRef]

40. Lorenzo-Lamosa, M.L.; Remuñán-López, C.; Vila-Jato, J.L.; Alonso, M.J. Design of microencapsulated chitosan microspheres for colonic drug delivery. J. Controll. Release 1998, 52, 109-118. [CrossRef]

41. Wang, L.-Y.; Ma, G.-H.; Su, Z.-G. Preparation of uniform sized chitosan microspheres by membrane emulsification technique and application as a carrier of protein drug. J. Controll. Release 2005, 106, 62-75. [CrossRef] [PubMed]

42. Shintaku, H.; Kuwabara, T.; Kawano, S.; Suzuki, T.; Kanno, I.; Kotera, H. Micro cell encapsulation and its hydrogel-beads production using microfluidic device. Microsyst. Technol. 2007, 13, 951-958. [CrossRef]

43. Liu, K.; Deng, Y.; Zhang, N.; Li, S.; Ding, H.; Guo, F.; Liu, W.; Guo, S.; Zhao, X.-Z. Generation of disk-like hydrogel beads for cell encapsulation and manipulation using a droplet-based microfluidic device. Microfluid. Nanofluid. 2012, 13, 761-767. [CrossRef]

44. Tumarkin, E.; Kumacheva, E. Microfluidic generation of microgels from synthetic and natural polymers. Chem. Soc. Rev. 2009, 38, 2161-2168. [CrossRef]

45. Park, J.I.; Saffari, A.; Kumar, S.; Günther, A.; Kumacheva, E. Microfluidic Synthesis of Polymer and Inorganic Particulate Materials. Ann. Rev. Mater. Res. 2010, 40, 415-443. [CrossRef]

46. Shepherd, R.F.; Conrad, J.C.; Rhodes, S.K.; Link, D.R.; Marquez, M.; Weitz, D.A.; Lewis, J.A. Microfluidic Assembly of Homogeneous and Janus Colloid-Filled Hydrogel Granules. Langmuir 2006, 22, 8618-8622. [CrossRef]

47. Bong, K.W.; Bong, K.T.; Pregibon, D.C.; Doyle, P.S. Hydrodynamic Focusing Lithography. Angew. Chem. Int. Ed. 2010, 49, 87-90. [CrossRef]

48. Kim, C.; Park, K.-S.; Kim, J.; Jeong, S.-G.; Lee, C.-S. Microfluidic synthesis of monodisperse pectin hydrogel microspheres based on in situ gelation and settling collection. J. Chem. Technol. Biotechnol. 2017, 92, 201-209. [CrossRef]

49. Hati, A.G.; Bassett, D.C.; Ribe, J.M.; Sikorski, P.; Weitz, D.A.; Stokke, B.T. Versatile, cell and chip friendly method to gel alginate in microfluidic devices. Lab Chip 2016, 16, 3718-3727. [CrossRef]

50. Utech, S.; Prodanovic, R.; Mao, A.S.; Ostafe, R.; Mooney, D.J.; Weitz, D.A. Microfluidic Generation of Monodisperse, Structurally Homogeneous Alginate Microgels for Cell Encapsulation and 3D Cell Culture. Adv. Healthcare Mater. 2015, 4, 1628-1633. [CrossRef]

51. Zhang, H.; Tumarkin, E.; Sullan, R.M.A.; Walker, G.C.; Kumacheva, E. Exploring Microfluidic Routes to Microgels of Biological Polymers. Macromol. Rapid Commun. 2007, 28, 527-538. [CrossRef]

52. Marquis, M.; Renard, D.; Cathala, B. Microfluidic Generation and Selective Degradation of Biopolymer-Based Janus Microbeads. Biomacromolecules 2012, 13, 1197-1203. [CrossRef] [PubMed]

53. Zhang, H.; Tumarkin, E.; Peerani, R.; Nie, Z.; Sullan, R.M.A.; Walker, G.C.; Kumacheva, E. Microfluidic Production of Bi-opolymer Microcapsules with Controlled Morphology. J. Am. Chem. Soc. 2006, 128, 12205-12210. [CrossRef] [PubMed]

54. Iwamoto, S.; Nakagawa, K.; Sugiura, S.; Nakajima, M. Preparation of gelatin microbeads with a narrow size distribution using microchannel emulsification. AAPS PharmSciTech 2002, 3, 72-76. [CrossRef] [PubMed]

55. Xu, Q.B.; Hashimoto, M.; Dang, T.T.; Hoare, T.; Kohane, D.S.; Whitesides, G.M.; Langer, R.; Anderson, D.G. Preparation of Monodisperse Biodegradable Polymer Microparticles Using a Microfluidic Flow-Focusing Device for Controlled Drug Delivery. Small 2009, 5, 1575-1581. [CrossRef]

56. Hati, A.G.; Szymborski, T.R.; Steinacher, M.; Amstad, E. Production of monodisperse drops from viscous fluids. Lab Chip 2018. [CrossRef]

57. Visser, C.W.; Kamperman, T.; Karbaat, L.P.; Lohse, D.; Karperien, M. In-air microfluidics enables rapid fabrication of emulsions, suspensions, and 3D modular (bio) materials. Sci. Adv. 2018, 4. [CrossRef] 
58. Kamperman, T.; Trikalitis, V.D.; Karperien, M.; Visser, C.W.; Leijten, J. Ultrahigh-Throughput Production of Monodisperse and Multifunctional Janus Microparticles Using in-Air Microfluidics. ACS Appl. Mater. Interfaces 2018, 10, 23433-23438. [CrossRef] [PubMed]

59. Wang, Y.T.; Zhang, X.X.; Shang, L.R.; Zhao, Y.J. Thriving microfluidic technology. Sci. Bull. 2021, 66, 9-12. [CrossRef]

60. Lai, Y.; He, D.; Hu, Y. Indentation adhesion of hydrogels over a wide range of length and time scales. Extreme Mech. Lett. 2019, 31, 100540. [CrossRef]

61. Aufderhorst-Roberts, A.; Baker, D.; Foster, R.J.; Cayre, O.; Mattsson, J.; Connell, S.D. Nanoscale mechanics of microgel particles. Nanoscale 2018, 10, 16050-16061. [CrossRef] [PubMed]

62. Kwon, S.; Yang, W.; Moon, D.; Kim, K.S. Comparison of Cancer Cell Elasticity by Cell Type. J. Cancer 2020, 11, 5403-5412. [CrossRef] [PubMed]

63. Lin, D.C.; Horkay, F. Nanomechanics of polymer gels and biological tissues: A critical review of analytical approaches in the Hertzian regime and beyond. Soft Matter 2008, 4, 669-682. [CrossRef]

64. Garcia, R. Nanomechanical mapping of soft materials with the atomic force microscope: Methods, theory and applications. Chem. Soc. Rev. 2020, 49, 5850-5884. [CrossRef]

65. Lekka, M.; Sainz-Serp, D.; Kulik, A.J.; Wandrey, C. Hydrogel Microspheres: Influence of Chemical Composition on Surface Morphology, Local Elastic Properties, and Bulk Mechanical Characteristics. Langmuir 2004, 20, 9968-9977. [CrossRef] [PubMed]

66. Dehghani, E.S.; Ramakrishna, S.N.; Spencer, N.D.; Benetti, E.M. Controlled Crosslinking Is a Tool To Precisely Modulate the Nanomechanical and Nanotribological Properties of Polymer Brushes. Macromolecules 2017, 50, 2932-2941. [CrossRef]

67. Shiratori, S.S.; Rubner, M.F. pH-dependent thickness behaviour of sequentially adsorbed layers of weak polyelectrolytes. Macromolecules 2000, 33, 4213-4219. [CrossRef]

68. Zavgorodnya, O.; Serpe, M.J. Assembly of poly(N-isopropylacrylamide)-co-acrylic acid microgel thin films on polyelectrolyte multilayers: Effects of polyelectrolyte layer thickness, surface charge, and microgel solution pH. Colloid Polym. Sci. 2011, 289, 591-602. [CrossRef]

69. Scheffold, F. Pathways and challenges towards a complete characterization of microgels. Nat. Commun. 2020, 11, 4315. [CrossRef]

70. Maza, E.; von Bilderling, C.; Cortez, M.L.; Díaz, G.; Bianchi, M.; Pietrasanta, L.I.; Giussi, J.M.; Azzaroni, O. Layer-by-Layer Assembled Microgels Can Combine Conflicting Properties: Switchable Stiffness and Wettability without Affecting Permeability. Langmuir 2018, 34, 3711-3719. [CrossRef]

71. Zhu, P.-W.; Chen, L. Effects of cosolvent partitioning on conformational transitions and chain flexibility of thermoresponsive microgels. Phys. Rev. E 2019, 99, 022501. [CrossRef]

72. Backes, S.; Krause, P.; Tabaka, W.; Witt, M.U.; von Klitzing, R. Combined Cononsolvency and Temperature Effects on Ad-sorbed PNIPAM Microgels. Langmuir 2017, 33, 14269-14277. [CrossRef]

73. Backes, S.; Von Klitzing, R. Nanomechanics and Nanorheology of Microgels at Interfaces. Polymers 2018, 10, 978. [CrossRef] [PubMed]

74. Burmistrova, A.; Richter, M.; Uzum, C.; Klitzing, R.V. Effect of cross-linker density of P (NIPAM-co-AAc) microgels at solid surfaces on the swelling/shrinking behaviour and the Young's modulus. Colloid Polymer Sci. 2011, 289, 613-624. [CrossRef]

75. Nyström, L.; Álvarez-Asencio, R.; Frenning, G.; Saunders, B.R.; Rutland, M.W.; Malmsten, M. Electrostatic Swelling Transitions in Surface-Bound Microgels. ACS Appl. Mater. Interfaces 2016, 8, 27129-27139. [CrossRef]

76. Virumbrales-Muñoz, M.; Santos-Vizcaino, E.; Paz, L.; Gallardo-Moreno, A.M.; Orive, G.; Hernandez, R.M.; Doblaré, M.; Gonzalez-Martin, M.L.; Fernández, L.J.; Pedraz, J.L.; et al. Force spectroscopy-based simultaneous topographical and me-chanical characterization to study polymer-to-polymer interactions in coated alginate microspheres. Sci. Rep. 2019, 9, 20112. [CrossRef] [PubMed]

77. Li, G.; Varga, I.; Kardos, A.; Dobryden, I.; Claesson, P.M. Temperature-Dependent Nanomechanical Properties of Adsorbed Poly-NIPAm Microgel Particles Immersed in Water. Langmuir 2021, 37, 1902-1912. [CrossRef]

78. Mohapatra, H.; Kruger, T.M.; Lansakara, T.I.; Tivanski, A.V.; Stevens, L.L. Core and surface microgel mechanics are differ-entially sensitive to alternative crosslinking concentrations. Soft Matter 2017, 13, 5684-5695. [CrossRef] [PubMed]

79. Bachman, H.; Brown, A.C.; Clarke, K.C.; Dhada, K.S.; Douglas, A.; Hansen, C.E.; Herman, E.; Hyatt, J.S.; Kodlekere, P.; Meng, Z.; et al. Ultrasoft, highly deformable microgels. Soft Matter 2015, 11, 2018-2028. [CrossRef]

80. Matsui, S.; Kureha, T.; Hiroshige, S.; Shibata, M.; Uchihashi, T.; Suzuki, D. Fast Adsorption of Soft Hydrogel Microspheres on Solid Surfaces in Aqueous Solution. Angew. Chem. Int. Ed. 2017, 56, 12146-12149. [CrossRef]

81. Theret, D.P.; Levesque, M.J.; Sato, M.; Nerem, R.M.; Wheeler, L.T. The Application of a Homogeneous Half-Space Model in the Analysis of Endothelial Cell Micropipette Measurements. J. Biomech. Eng. 1988, 110, 190-199. [CrossRef]

82. Daza, R.; Gonzalez-Bermudez, B.; Cruces, J.; De la Fuente, M.; Plaza, G.R.; Arroyo-Hernandez, M.; Elices, M.; Perez-Rigueiro, J.; Guinea, G.V. Comparison of cell mechanical measurements provided by Atomic Force Microscopy (AFM) and Micropipette Aspiration (MPA). J. Mech. Behav. Biomed. Mater. 2019, 95, 103-115. [CrossRef] [PubMed]

83. Zhou, E.H.; Lim, C.T.; Quek, S.T. Finite element simulation of the micropipette aspiration of a living cell undergoing large viscoelastic deformation. Mech. Adv. Mater. Struct. 2005, 12, 501-512. [CrossRef]

84. Sakai, A.; Murayama, Y.; Fujiwara, K.; Fujisawa, T.; Sasaki, S.; Kidoaki, S.; Yanagisawa, M. Increasing Elasticity through Changes in the Secondary Structure of Gelatin by Gelation in a Microsized Lipid Space. ACS Cent. Sci. 2018, 4, 477-483. [CrossRef] 
85. Kleinberger, R.M.; Burke, N.A.D.; Dalnoki-Veress, K.; Stover, H.D.H. Systematic study of alginate-based microcapsules by micropipette aspiration and confocal fluorescence microscopy. Mater. Sci. Eng. C Mater. Biol. Appl. 2013, 33, 4295-4304. [CrossRef]

86. Li, Y.; Sarıyer, O.S.; Ramachandran, A.; Panyukov, S.; Rubinstein, M.; Kumacheva, E. Universal behavior of hydrogels confined to narrow capillaries. Sci. Rep. 2015, 5, 17017. [CrossRef]

87. Wyss, H.M.; Franke, T.; Mele, E.; Weitz, D.A. Capillary micromechanics: Measuring the elasticity of microscopic soft objects. Soft Matter 2010, 6, 4550-4555. [CrossRef]

88. Li, S.; Yu, H.; Li, T.-D.; Chen, Z.; Deng, W.; Anbari, A.; Fan, J. Understanding transport of an elastic, spherical particle through a confining channel. Appl. Phys. Lett. 2020, 116, 103705. [CrossRef]

89. Byun, S.; Son, S.; Amodei, D.; Cermak, N.; Shaw, J.; Kang, J.H.; Hecht, V.C.; Winslow, M.M.; Jacks, T.; Mallick, P.; et al. Characterizing deformability and surface friction of cancer cells. Proc. Natl. Acad. Sci. USA 2013, 110, 7580-7585. [CrossRef] [PubMed]

90. Adamo, A.; Sharei, A.; Adamo, L.; Lee, B.; Mao, S.; Jensen, K.F. Microfluidics-Based Assessment of Cell Deformability. Anal. Chem. 2012, 84, 6438-6443. [CrossRef]

91. Nyberg, K.D.; Scott, M.B.; Bruce, S.L.; Gopinath, A.B.; Bikos, D.; Mason, T.G.; Kim, J.W.; Choi, H.S.; Rowat, A.C. The physical origins of transit time measurements for rapid, single cell mechanotyping. Lab Chip 2016, 16, 3330-3339. [CrossRef]

92. Gossett, D.R.; Tse, H.T.K.; Lee, S.A.; Ying, Y.; Lindgren, A.G.; Yang, O.O.; Rao, J.; Clark, A.T.; Di Carlo, D. Hydrodynamic stretching of single cells for large population mechanical phenotyping. Proc. Natl. Acad. Sci. USA 2012, 109, 7630-7635. [CrossRef]

93. Mietke, A.; Otto, O.; Girardo, S.; Rosendahl, P.; Taubenberger, A.; Golfier, S.; Ulbricht, E.; Aland, S.; Guck, J.; Fischer-Friedrich, E. Extracting Cell Stiffness from Real-Time Deformability Cytometry: Theory and Experiment. Biophys. J. 2015, 109, 2023-2036. [CrossRef] [PubMed]

94. Urbanska, M.; Muñoz, H.E.; Shaw Bagnall, J.; Otto, O.; Manalis, S.R.; Di Carlo, D.; Guck, J. A comparison of microfluidic methods for high-throughput cell deformability measurements. Nat. Methods 2020, 17, 587-593. [CrossRef]

95. Fregin, B.; Czerwinski, F.; Biedenweg, D.; Girardo, S.; Gross, S.; Aurich, K.; Otto, O. High-throughput single-cell rheology in complex samples by dynamic real-time deformability cytometry. Nat. Commun. 2019, 10, 415. [CrossRef] [PubMed]

96. Belotti, Y.; Tolomeo, S.; Conneely, M.J.; Huang, T.; McKenna, S.J.; Nabi, G.; McGloin, D. High-Throughput, Time-Resolved Mechanical Phenotyping of Prostate Cancer Cells. Sci. Rep. 2019, 9, 9. [CrossRef]

97. Saadat, A.; Huyke, D.A.; Oyarzun, D.I.; Escobar, P.V.; Øvreeide, I.H.; Shaqfeh, E.S.G.; Santiago, J.G. A system for the highthroughput measurement of the shear modulus distribution of human red blood cells. Lab Chip 2020, 20, 2927-2936. [CrossRef]

98. Mokbel, M.; Mokbel, D.; Mietke, A.; Träber, N.; Girardo, S.; Otto, O.; Guck, J.; Aland, S. Numerical Simulation of Real-Time Deformability Cytometry To Extract Cell Mechanical Properties. ACS Biomater. Sci. Eng. 2017, 3, 2962-2973. [CrossRef]

99. Witkowski, T.; Ling, S.; Praetorius, S.; Voigt, A. Software concepts and numerical algorithms for a scalable adaptive parallel finite element method. Adv. Comput. Math. 2015, 41, 1145-1177. [CrossRef]

100. Ahmmed, S.M.; Bithi, S.S.; Pore, A.A.; Mubtasim, N.; Schuster, C.; Gollahon, L.S.; Vanapalli, S.A. Multi-sample deformability cytometry of cancer cells. APL Bioeng. 2018, 2, 032002. [CrossRef] [PubMed]

101. Liu, Y.; Galior, K.; Ma, V.P.-Y.; Salaita, K. Molecular Tension Probes for Imaging Forces at the Cell Surface. Acc. Chem. Res. 2017, 50, 2915-2924. [CrossRef]

102. Neubauer, J.W.; Hauck, N.; Männel, M.J.; Seuss, M.; Fery, A.; Thiele, J. Mechanoresponsive Hydrogel Particles as a Platform for Three-Dimensional Force Sensing. ACS Appl. Mater. Interfaces 2019, 11, 26307-26313. [CrossRef] [PubMed]

103. Scarcelli, G.; Yun, S.H. Confocal Brillouin microscopy for three-dimensional mechanical imaging. Nat. Photon. 2008, 2, 39-43. [CrossRef] [PubMed]

104. Wu, P.-J.; Kabakova, I.V.; Ruberti, J.W.; Sherwood, J.M.; Dunlop, I.E.; Paterson, C.; Török, P.; Overby, D.R. Water content, not stiffness, dominates Brillouin spectroscopy measurements in hydrated materials. Nat. Methods 2018, 15, 561-562. [CrossRef]

105. Scarcelli, G.; Yun, S.H. Reply to 'Water content, not stiffness, dominates Brillouin spectroscopy measurements in hydrated materials'. Nat. Methods 2018, 15, 562-563. [CrossRef] [PubMed]

106. Ferry, J.D. Viscoelastic Properties of Polymers; John Wiley \& Sons, Inc.: New York, NY, USA, 1980.

107. Lekka, M.; Laidler, P.; Gil, D.; Lekki, J.; Stachura, Z.; Hrynkiewicz, A.Z. Elasticity of normal and cancerous human bladder cells studied by scanning force microscopy. Eur. Biophys. J. 1999, 28, 312-316. [CrossRef]

108. Targosz-Korecka, M.; Brzezinka, G.D.; Malek, K.E.; Stępień, E.; Szymonski, M. Stiffness memory of EA.hy926 endothelial cells in response to chronic hyperglycemia. Cardiovasc. Diabetol. 2013, 12, 96. [CrossRef]

109. Szymonski, M.; Targosz-Korecka, M.; Malek-Zietek, K.E. Nano-mechanical model of endothelial dysfunction for AFM-based diagnostics at the cellular level. Pharmacol. Rep. 2015, 67, 728-735. [CrossRef]

110. Mokrozub, V.V.; Lazarenko, L.M.; Sichel, L.M.; Babenko, L.P.; Lytvyn, P.M.; Demchenko, O.M.; Melnichenko, Y.O.; Boyko, N.V.; Biavati, B.; DiGioia, D.; et al. The role of beneficial bacteria wall elasticity in regulating innate immune response. EPMA J. 2015, 6, 13. [CrossRef] 